\title{
NUMERICAL STUDY OF OXYGEN UPTAKE BY LAYERS OF HEMOGLOBIN SOLUTION
}

\author{
Howard KUTCHAI \\ Department of Biostatistics, School of Public Health, The University of Michigan, Ann Arbor, \\ Michigan, U.S.A. \\ and \\ Institute of Physiology ${ }^{1}$, University of Oslo, Oslo, Norway
}

\begin{abstract}
Numerical solutions have been obtained for the equations describing $\mathrm{O}_{2}$ uptake by layers of concentrated hemoglobin solution $0.25,0.5,1,1.6,2,3.6,5,10$, and $20 \mu$ thick. The results indicate that the diffusion of oxyhemoglobin has almost no effect on the rate of oxygenation of the $0.25 \mu$ layer, but its influence increases with increasing layer thickness, so that it shortens the time required to reach $50 \%$ saturation in the $1.6 \mu$ layer by $23 \%$ and in the $5 \mu$ layer by $34 \%$. For the $1.6 \mu$ layer, which might be considered a model red blood cell, the results suggest that the rate at which $\mathrm{O}_{2}$ reacts with hemoglobin is of primary importance early in the uptake process, but that later the diffusion of $\mathrm{O}_{2}$ into the deeper parts of the layer becomes rate-limiting.
\end{abstract}

$\begin{array}{ll}\text { Facilitated diffusion } & \begin{array}{l}\text { Oxygen diffusion } \\ \text { Oxyhemoglobin }\end{array}\end{array}$

The partial differential equations that describe the diffusion and chemical reaction of $\mathrm{O}_{2}$ in $\mathrm{Hb}$ solution are nonlinear and thus not solvable by analytical methods. For this reason much of the theoretical work done in this area has involved approximate solutions to the diffusion equations or solutions to approximations of the diffusion equations (see Roughton (1959) for a thorough review). Most of this work is due to Roughton, Forster, and their associates, who have been extremely inventive in wresting important insights from seemingly intractable equations. The electronic digital computer has made it practical to solve the diffusion equations numerically. The advantages of this approach are that it can deal with the nonlinearities present in the equations and theoretically solutions may be had with whatever accuracy is desired.

Accepted for publication 20 May 1970.

${ }^{1}$ Reprint requests: McCollum-Pratt Institute, The Johns Hopkins University, Baltimore, Maryland 21218, U.S.A. 
Nicoison and Roughton (1951) and Klug, Kreuzer and Roughton (1956) employed numerical approaches to solving the diffusion equations. Forster (1964) has reported on the numerical integration of the diffusion equations in a biconcave disc. Moll (1968) used numerical solutions of the diffusion equations to model the uptake and release of $\mathrm{O}_{2}$ by 1.6 and $3.6 \mu$ layers of $\mathrm{Hb}$ solution. He found significant effects of $\mathrm{HbO}_{2}$ diffusion on the uptake and release processes in both layers, but computed larger effects for the $3.6 \mu$ layer. He also found that while the time course calculated for deoxygenation of $1.6 \mu$ layers matched quite closely experimental determinations on human RBCs, that computed for oxygenation was much faster than $\mathrm{RBCs}$ have been observed to take up $\mathrm{O}_{2}$.

I have obtained numerical solutions for the equations describing $\mathrm{O}_{2}$ uptake by layers of concentrated $\mathrm{Hb}$ solutions $0.25,0.5,1,1.6,2,3.6,5,10$, and $20 \mu$ thick. The solutions indicate that the diffusion of $\mathrm{HbO}_{2}$ has almost no effect on the rate of oxygenation of the $0.25 \mu$ layer, but its influence increases quickly with layer thickness, so that it shortens the time required to reach $50 \%$ saturation in the $1.6 \mu$ layer by $23 \%$ and that in the $5 \mu$ layer by $34 \%$. For the $1.6 \mu$ layer I attempted to estimate the relative importance of diffusion and reaction parameters in determining the overall rate of $\mathrm{O}_{2}$ uptake. The results suggest that the rate at which $\mathrm{O}_{2}$ reacts with $\mathrm{Hb}$ is of primary importance early in the uptake process, but that later the diffusion coefficient of $\mathrm{O}_{2}$ becomes the most important parameter.

The discrepancy between observed and calculated rates of $\mathrm{O}_{2}$ uptake by RBCs is discussed. I argue that the $\mathrm{O}_{2}$ diffusion resistance of the $\mathrm{RBC}$ membrane, which is generally regarded as the cause of the discrepancy, is probably not large enough to explain the difference between theory and experiment.

\section{Methods}

THE MODEL

I have used a mathematical model to investigate the behavior of a layer of concentrated $\mathrm{Hb}$ solution, initially free of $\mathrm{O}_{2}$, when exposed to $100 \mathrm{~mm} \mathrm{Hg} \mathrm{O}_{2}$ tension at both surfaces (fig. 1). The mathematical formulation of the model consists of the onedimensional diffusion equations for $\mathrm{O}_{2}$ and $\mathrm{HbO}_{2}$ plus 6 conditions on the solution functions $\mathrm{C}_{\mathrm{O}_{2}}(\mathrm{x}, \mathrm{t})$ and $\mathrm{C}_{\mathrm{HbO}_{2}}(\mathrm{x}, \mathrm{t})$, the concentrations of $\mathrm{O}_{2}$ and $\mathrm{HbO}_{2}$, respectively.

The reaction of $\mathrm{Hb}$ with $\mathrm{O}_{2}$ has been assumed to be the one step reaction

$$
\mathrm{Hb}+\mathrm{O}_{2} \underset{\mathrm{k}}{\stackrel{\mathrm{k}^{\prime}}{\rightleftharpoons}} \mathrm{HbO}_{2}
$$

where $\mathrm{k}^{\prime}$ and $\mathrm{k}$ are the forward and backward reaction rate coefficients, respectively. This representation is not consistent with the widely accepted concept of a four step reaction of $\mathrm{O}_{2}$ with $\mathrm{Hb}$. In addition, eq. (1) predicts a hyperbolic $\mathrm{Hb}-\mathrm{O}_{2}$ equilibrium curve that cannot closely fit the sigmoid curve of whole blood. The principal justifification for my using this oversimplified reaction scheme is that it can fairly closely 


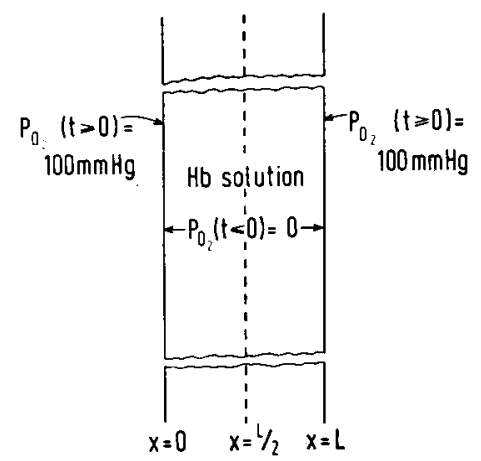

Fig. 1. Schematic diagram of the physical situation considered.

represent the kinetics of $\mathrm{O}_{2}$ uptake and release (see Roughton, 1959).

The total $\mathrm{Hb}$ concentration $\left(\mathrm{C}_{\mathrm{t}}\right)$ is assumed to be the same everywhere in the layer, so that

$$
\mathrm{C}_{\mathrm{Hb}}+\mathrm{C}_{\mathrm{HbO}_{2}}=\mathrm{C}_{\mathrm{t}}
$$

holds for all values of $\mathrm{x}$. Thus $\mathrm{C}_{\mathrm{Hb}}$ can be expressed in terms of $\mathrm{C}_{\mathrm{HbO}_{2}}$ and need not be considered separately.

The diffusion equations for the diffusion and chemical reaction of $\mathrm{O}_{2}$ and $\mathrm{HbO}_{2}$ in a one-dimensional system are

$$
\begin{aligned}
& \frac{\partial \mathrm{C}_{\mathrm{O}_{2}}}{\partial \mathrm{t}}=\mathrm{D}_{\mathrm{O}_{2}} \frac{\partial^{2} \mathrm{C}_{\mathrm{O}_{2}}}{\mathrm{dx}{ }^{2}}-\mathrm{k}^{\prime} \mathrm{C}_{\mathrm{O}_{2}}\left(\mathrm{C}_{\mathrm{t}}-\mathrm{C}_{\mathrm{HbO}_{2}}\right)+\mathrm{kC}_{\mathrm{HbO}_{2}} \\
& \frac{\partial \mathrm{C}_{\mathrm{HbO}_{2}}}{\partial \mathrm{t}}=\mathrm{D}_{\mathrm{HbO}_{2}} \frac{\partial^{2} \mathrm{C}_{\mathrm{HbO}_{2}}}{\partial \mathrm{x}^{2}}+\mathrm{k}^{\prime} \mathrm{C}_{\mathrm{O}_{2}}\left(\mathrm{C}_{\mathrm{t}}-\mathrm{C}_{\mathrm{HbO}_{2}}\right)-\mathrm{kC}_{\mathrm{HbO}_{2}}
\end{aligned}
$$

where the D's are the diffusion coefficients of the species denoted by subscripts. Note that $\mathrm{C}_{\mathrm{Hb}}$ has been expressed as $\mathrm{C}_{\mathrm{t}}-\mathrm{C}_{\mathrm{HbO}_{2}} \cdot \mathrm{C}_{\mathrm{HbO}_{2}}$ and $\mathrm{C}_{\mathrm{t}}$ are in mole heme $/ \mathrm{ml}$.

To specify unique solutions to eqs. (3) and (4) appropriate initial conditions and boundary values must be imposed. Because the $\mathrm{O}_{2}$ and $\mathrm{HbO}_{2}$ concentration profiles must be symmetrical about the center of the layer we need only consider the range $0 \leqslant \mathrm{X} \leqslant \mathrm{L} / 2$.

It is assumed that initially the layer is completely free of $\mathrm{O}_{2}$ and at $\mathrm{t}=0$ its surfaces are exposed to an $\mathrm{O}_{2}$ tension of $100 \mathrm{~mm} \mathrm{Hg}$, so

$$
\mathrm{C}_{\mathrm{O}_{2}}(\mathrm{x}, 0)=0, \mathrm{x}>0
$$

$$
\mathrm{C}_{\mathrm{HbO}_{2}}(\mathrm{x}, 0) / 0, \mathrm{x} \geqslant 0 \text {. }
$$

Since the $\mathrm{O}_{2}$ tension at the boundaries is $100 \mathrm{~mm} \mathrm{Hg}$ for $\mathrm{t} \geqslant 0$

$$
\mathrm{C}_{\mathrm{O}_{2}}(0, \mathrm{t})=\alpha_{\mathrm{O}_{2}}^{\mathrm{Hb} \text { soln }} \cdot 100
$$


where $\alpha_{\mathrm{O}_{2}}^{\mathrm{Hb} \text { soln }}$ is the solubility of $\mathrm{O}_{2}$ in the $\mathrm{Hb}$ solution expressed in $\mathrm{mole} /(\mathrm{ml} \cdot \mathrm{mm} \mathrm{Hg})$.

Because $\mathrm{HbO}_{2}$ cannot cross the boundaries of the layer

$$
\left.\frac{\partial \mathrm{C}_{\mathrm{HbO}_{2}}}{\partial \mathrm{x}}\right|_{\mathbf{x}=0}=0, \mathrm{t} \geqslant 0 .
$$

For reasons of symmetry the minimum concentrations of $\mathrm{O}_{2}$ and $\mathrm{HbO}_{2}$ must occur in the middle of the layer, so

$$
\begin{aligned}
& \left.\frac{\partial \mathrm{C}_{\mathrm{O}_{2}}}{\partial \mathrm{x}}\right|_{\mathrm{x}=\mathrm{L} / 2}=0, \mathrm{t} \geqslant 0 \\
& \left.\frac{\partial \mathrm{C}_{\mathrm{HbO}_{2}}}{\partial \mathrm{x}}\right|_{x=L / 2}=0, t \geqslant 0 .
\end{aligned}
$$

The mathematical model is then eqs. (3) and (4) subject to the constraints of eqs. (5) - (10). The effects of $\mathrm{HbO}_{2}$ diffusion were investigated by comparing numerical solutions of the model for $\mathrm{D}_{\mathrm{HbO}_{2}}=0$ to those for reasonable values of $\mathrm{D}_{\mathrm{HbO}_{2}}$. The relative importance of $\mathrm{D}_{\mathrm{O}_{2}}, \mathrm{D}_{\mathrm{HbO}_{2}}, \mathrm{k}^{\prime}$, and $\mathrm{k}$ was estimated from the effects of changing these constants one at a time.

\section{THE NUMERICAL METHOD}

Because of the nonlinear chemical reaction term in eqs. (3) and (4) analytical methods of solution cannot be applied. I have used a finite difference method to obtain numerical solutions to eqs. (3) and (4) subject to the conditions imposed by eqs. (5)-(10). The method, originally due to SAUL'YeV (1964) and modified by CARNAHAN, LUTHER and WILKes (1969), uses the following finite difference forms as approximations to $\partial \mathrm{C} / \partial \mathrm{t}$ and $\partial^{2} \mathrm{C} / \partial \mathrm{x}^{2}$ :

$$
\begin{aligned}
& \frac{\partial \mathrm{C}}{\partial \mathrm{t}} \mid=\frac{\mathrm{C}\left(\mathrm{x}_{\mathrm{i}}, \mathrm{t}_{\mathrm{j}+1}\right)-\mathrm{C}\left(\mathrm{x}_{\mathrm{i}}, \mathrm{t}_{\mathrm{j}}\right)}{\Delta \mathrm{t}} \\
& \frac{\partial^{2} \mathrm{C}, \mathrm{t}_{3}}{\partial \mathrm{x}^{2}} \mid=\frac{\mathrm{C}\left(\mathrm{x}_{\mathrm{i}-1}, \mathrm{t}_{\mathrm{j}+1}\right)-\mathrm{C}\left(\mathrm{x}_{\mathrm{i}}, \mathrm{t}_{\mathrm{j}+1}\right)-\mathrm{C}\left(\mathrm{x}_{\mathrm{i}}, \mathrm{t}_{\mathrm{j}}\right)+\mathrm{C}\left(\mathrm{x}_{\mathrm{i}+1}, \mathrm{t}_{\mathrm{j}}\right)}{(\Delta \mathrm{x})^{2}} \\
& \left.\frac{\partial^{2} \mathrm{C}, \mathrm{C}}{\partial \mathrm{x}^{2}}\right|_{\mathrm{x}_{\mathrm{f}}, \mathrm{t}_{j}}
\end{aligned}
$$

The method is explicit in that concentrations are computed directly without solving systems of algebraic equations. Knowing all concentrations at $t=t_{0}$ one calculates the concentrations at the next time level $\left(t=t_{0}+\Delta t\right)$ by using (12) to represent the second 
derivatives and proceeding in the $+x$ direction. Upon reaching a boundary (in our case the center of the layer) one calculates the concentrations at the next time level $\left(t=t_{0}+2 \Delta t\right)$ by proceeding in the $-x$ direct in using eq. (13) to represent the second derivatives. The references should be consulted for details of the method.

Equations (11)-(13) were used to approximate $\partial \mathrm{C}_{\mathrm{O}_{2}} / \partial \mathrm{t}, \partial \mathrm{C}_{\mathrm{HbO}_{2}} / \partial \mathrm{t}, \partial^{2} \mathrm{C}_{\mathrm{O}_{2}} / \partial \mathrm{x}^{2}$, and $\partial^{2} \mathrm{C}_{\mathrm{HbO}} / \partial \mathrm{x}^{2}$ for $\mathrm{t} \geqslant 0,0<\mathrm{x}<\mathrm{L} / 2$. For approximating the chemical kinetic terms in the partial differential equations I assumed that over the time step from $t_{i}$ to $t_{i+1}$, $\mathrm{C}_{\mathrm{O}_{2}}=\mathrm{C}_{\mathrm{O}_{2}}\left(\mathrm{t}_{\mathrm{i}}\right)$ and $\mathrm{C}_{\mathrm{HbO}_{2}}=\mathrm{C}_{\mathrm{HbO}_{2}}\left(\mathrm{t}_{\mathrm{i}}\right)$ for each value of $\mathrm{x}$.

The method was programmed in FORTRAN-IV using double precision arithmetic for the IBM 360/67 at the University of Michigan Computing Center and in FORTRAN-II for the Nord 1 computer at the Physiological Institute of the University of Oslo. The results from the two computers were nearly identical, which indicates that roundoff error was negligible. The results reported here are from the Nord 1.

The half-thickness of the layer was divided into 10 subintervals, so that $\Delta x=L / 20$. The value to be used for $\Delta t$ was determined by trial and error. If $\Delta t$ was made too large the solutions failed to converge. Values of $\Delta t$ ranged from $1 \times 10^{-7} \sec$ for $0.25 \mu$ layers to $2 \times 10^{-5} \mathrm{sec}$ for $20 \mu$ laycrs. Most methods for numcrically integrating partial differential equations use fairly large amounts of computing time. In general larger times were required for larger values of $\mathrm{L}$, the solutions for $5 \mu$ layers taking about 2 min computing time on the IBM $360 / 67$.

\section{CONSTANTS USED IN THE CALCULATIONS}

Table 1 gives the values of constants used in the calculations. Most of them are identical to the values used by MoLL (1968) which I believe to be the most reliable values currently available for physiological temperature and $\mathrm{pH}$.

\section{TABLE 1}

Constants used in the calculations.

\begin{tabular}{|c|c|c|}
\hline Constant & Value & Reference \\
\hline $\mathbf{D}_{2}$ & $8 \times 10^{-6} \mathrm{~cm}^{2} / \mathrm{sec}$ & $\begin{array}{l}\text { GroTE and THEWS (1962) } \\
\text { KELLER and FRIEDLANDER (1966) }\end{array}$ \\
\hline $\mathrm{D}_{\mathrm{HbO}_{2}}$ & $4.5 \times 10^{-8} \mathrm{~cm}^{2} / \mathrm{sec}$ & MoLL (1966) \\
\hline $\mathrm{k}^{\prime}$ & $3.5 \times 10^{9} \mathrm{ml} /($ mole sec $)$ & GiBsun et al. (1955) \\
\hline k & $44 \mathrm{sec}^{-1}$ & GrBSON et al. (1955) \\
\hline$\alpha \begin{array}{l}\mathrm{Fb} \text { soin } \\
\mathrm{O}_{2}\end{array}$ & $1.51 \times 10^{-9} \frac{\mathrm{mole}}{\mathrm{ml} \mathrm{mm} \mathrm{Hg}}$ & SENDROY et al. (1934) \\
\hline $\mathrm{C}_{t}$ & $\begin{array}{l}2 \times 10^{-5} \mathrm{~mole} \text { heme } / \mathrm{ml} \\
(=32.25 \mathrm{~g} \mathrm{Hb} / 100 \mathrm{ml})\end{array}$ & $\longrightarrow$ \\
\hline
\end{tabular}

$\mathrm{D}_{\mathrm{O}_{2}}$ has been measured in $\mathrm{Hb}$ solutions up to a concentration of $30 \mathrm{~g} / 100 \mathrm{ml}$ by KELLER and FRIEDLANDER (1966). The value obtained by extrapolating their results to $33 \mathrm{~g} / 100 \mathrm{ml} \mathrm{Hb}$ concentration agrees well with the estimation of $\mathrm{D}_{\mathrm{O}_{2}}$ in human RBCs by GRoTE and Thews (1962). 
The diffusion coefficient of $\mathrm{Hb}$ has been measured in $\mathrm{Hb}$ solutions more concentrated than $30 \mathrm{~g} / 100 \mathrm{ml}$ by MoLL (1966).

The problems involved in treating the $\mathrm{Hb}-\mathrm{O}_{2}$ reaction as a single step reaction are discussed above. I chose $\mathrm{k}^{\prime}=3.5 \times 10^{9} \mathrm{ml} /\left(\mathrm{mole} \mathrm{sec}\right.$ ) and $\mathrm{k}=44 \mathrm{sec}^{-1}$ (GIBson et al., 1955).

All values chosen are intended to apply to solutions of human $\mathrm{Hb}$ at physiological temperature and $\mathrm{pH}$.

\section{Results and discussion}

EFFECTS OF LAYER THICKNESS

The model was solved for layer thickness $L=0.25,0.5,1,1.6,2,3.6,5,10$, and $20 \mu$.

TABLE 2

Effect of layer thickness on oxygen uptake by layers of hemoglobin solution.

\begin{tabular}{lrrrrrrrrr}
\hline Avg. saturation & \multicolumn{8}{c}{ time (msec) } \\
\cline { 2 - 10 } & $0.25 \mu$ & $0.5 \mu$ & $1 \mu$ & $1.6 \mu$ & $2 \mu$ & $3.6 \mu$ & $5 \mu$ & $10 \mu$ & $20 \mu$ \\
\hline $10 \%$ & 0.28 & 0.47 & 0.90 & 1.38 & 1.68 & 2.76 & 3.64 & 7.08 & 20.99 \\
$20 \%$ & 0.59 & 0.99 & 1.99 & 3.32 & 4.26 & 8.94 & 14.68 & 49.68 & 189.70 \\
$30 \%$ & 0.94 & 1.56 & 3.28 & 5.86 & 7.90 & 19.48 & 34.72 & 129.51 & 508.77 \\
$40 \%$ & 1.33 & 2.19 & 4.79 & 9.09 & 12.70 & 34.74 & 64.12 & 246.84 & 977.96 \\
$50 \%$ & 1.79 & 2.91 & 6.53 & 13.04 & 18.82 & 54.32 & 101.88 & 398.04 & 1582.68 \\
$60 \%$ & 2.35 & 3.76 & 8.56 & 17.75 & 26.08 & 77.72 & 147.00 & 578.40 & 2304.16 \\
$70 \%$ & 3.10 & 4.81 & 11.01 & 23.37 & 34.72 & 105.22 & 199.88 & 789.36 & 3147.52 \\
$80 \%$ & 4.25 & 6.32 & 14.20 & 30.46 & 45.48 & 138.82 & 264.24 & 1045.20 & 4169.77 \\
$90 \%$ & 7.35 & 9.98 & 20.56 & 43.03 & 63.84 & 193.24 & 367.04 & 1449.27 & 6280.92 \\
& & & & & & & & & \\
\hline
\end{tabular}

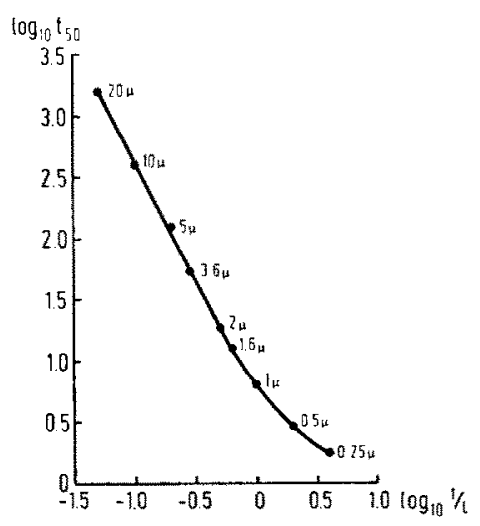

Fig. 2. The dependence of the time required for half-saturation $\left(t_{50}\right)$ on layer thickness $(L) . \log _{10}\left(t_{50}\right)$ is plotted against $\log _{10}(1 / \mathrm{L})$. The figures next to the data points give the layer thicknesses. 
The results are presented in table 2. Figure 2 is a graph of $\log t_{50}\left(t_{50}\right.$ is the time required to reach $50 \% \mathrm{O}_{2}$ saturation) vs $\log (1 / \mathrm{L})$. For $\mathrm{L}$ greater than $1.6 \mu$ the graph is linear with slope -2 , so that in this region $t_{50}$ is proportional to $\mathrm{L}^{2}$. This result might be expected if the diffusion of oxygen were the limiting process. For L less than $1.6 \mu$ the graph is curvilinear and it is tempting to speculate that in this range of $\mathrm{L}$ diffusion of $\mathrm{O}_{2}$ is so rapid that chemical reaction rates are important in determining the overall rate of $\mathrm{O}_{2}$ uptake.

TABLE 3

The effects of changing $\mathrm{D}_{\mathrm{O}_{2}}$ or $\mathrm{k}^{\prime}$ and $\mathrm{k}$ in $0.25 \mu$ and $5 \mu$ layers on their rates of $\mathrm{O}_{2}$ uptake.

\begin{tabular}{|c|c|c|c|c|c|c|}
\hline \multirow[t]{3}{*}{ Avg. saturation } & \multicolumn{6}{|c|}{ time (msec) } \\
\hline & \multicolumn{3}{|c|}{$0.25 \mu$ layer } & \multicolumn{3}{|l|}{$5 \mu$ layer } \\
\hline & $\begin{array}{l}\text { Values of } \\
\text { table } 1\end{array}$ & $\begin{array}{l}20 \% \text { incr. } \\
\text { in } \mathrm{D}_{\mathrm{O}_{2}}\end{array}$ & $\begin{array}{l}20 \% \text { incr. } \\
\mathrm{k}^{\prime} \text { and } \mathrm{k}\end{array}$ & $\begin{array}{l}\text { Valucs of } \\
\text { table } 1\end{array}$ & $\begin{array}{l}20 \% \text { incr. } \\
\text { in } \mathrm{D}_{\mathrm{O}_{2}}\end{array}$ & $\begin{array}{l}20 \% \text { incr. } \\
\mathrm{k}^{\prime} \text { and } \mathrm{k}\end{array}$ \\
\hline $10 \%$ & 0.28 & 0.27 & 0.25 & 3.64 & 3.36 & 3.28 \\
\hline $20 \%$ & 0.59 & 0.56 & 0.52 & 14.68 & 13.08 & 14.20 \\
\hline $30 \%$ & 0.94 & 0.90 & 0.82 & 34.72 & 30.72 & 34.20 \\
\hline $40 \%$ & 1.33 & 1.28 & 1.16 & 64.12 & 56.64 & 63.56 \\
\hline $50 \%$ & 1.79 & 1.72 & 1.56 & 101.88 & 90.08 & 101.36 \\
\hline $60 \%$ & 2.35 & 2.27 & 2.04 & 147.00 & 129.96 & 146.48 \\
\hline $70 \%$ & 3.10 & 3.00 & 2.68 & 199.88 & 176.36 & 199.32 \\
\hline $80 \%$ & 4.25 & 4.14 & 3.66 & 264.24 & 232.16 & 263.56 \\
\hline $90 \%$ & 7.35 & 7.21 & 6.28 & 367.04 & 320.00 & 366.00 \\
\hline
\end{tabular}

To test these ideas the model was solved for $\mathrm{L}=0.25$ and $5 \mu$ with a $20 \%$ increase in either $D_{\mathrm{O}_{2}}$ or $\mathrm{k}^{\prime}$ and $\mathrm{k}$. The results given in table 3 suggest that for the $0.25 \mu$ layer reaction rates are more important than $\mathrm{D}_{\mathrm{O}_{2}}$ and the reverse is true for the $5 \mu$ layer. It should be noted that for both thicknesses changing the less important parameter has a significant effect on the $t_{50}$. In the $5 \mu$ layer the reaction rates have an important effect effect on the initial rate of $\mathrm{O}_{2}$ uptake: I expect that for layers thicker than $5 \mu$ the primacy of diffusion coefficients becomes more clear cut and that for layers thinner than $0.25 \mu$ the limiting effects of reaction rates are more definite.

\section{THE EFFECT OF $\mathrm{HbO}_{2}$ DIFFUSION}

It has been shown that under some conditions $\mathrm{O}_{2}$ diffuses at a faster rate through hemoglobin solutions than through comparable layers of plasma or Hb solution saturated with CO (see Hfmmingsen, 1965 and Wittenberg, 1966 for reviews). The facilitated diffusion of $\mathrm{O}_{2}$ in $\mathrm{Hb}$ solutions has most often been attributed to $\mathrm{HbO}_{2}$ diffusion. Facilitated steady-state $\mathrm{O}_{2}$ diffusion through layers of intact human erythrocytes has been demonstrated by MoLL (1969) in $300 \mu$ layers and by KUTCHAI and Staub (1969) in $165 \mu$ layers. The role of facilitated diffusion in the uptake of $\mathrm{O}_{2}$ by hemoglobin solutions and RBCs has received relatively little attention. 
TABLE 4

Effect of $\mathrm{HbO}_{2}$ diffusion on $\mathrm{O}_{2}$ uptake by layers of hemoglobin solution of various thicknesses.

\begin{tabular}{llllrrrrrr}
\hline Avg. saturation & \multicolumn{7}{c}{$\%$ by which $\mathrm{HbO}_{2}$ diffusion shortens time to reach indicated saturation } \\
\cline { 2 - 11 } & $0.25 \mu$ & $0.5 \mu$ & $1 \mu$ & $1.6 \mu$ & $2 \mu$ & $3.6 \mu$ & $5 \mu$ & $10 \mu$ & $20 \mu$ \\
\hline $10 \%$ & 0.0 & 0.0 & 0.0 & 0.0 & 0.0 & 0.0 & 0.0 & 13.2 & 31.3 \\
$20 \%$ & 0.0 & 0.0 & 0.0 & 0.9 & 4.0 & 16.6 & 23.5 & 31.2 & 33.6 \\
$30 \%$ & 0.0 & 0.0 & 2.9 & 9.6 & 14.3 & 26.1 & 29.8 & 33.0 & 33.9 \\
$40 \%$ & 0.0 & 1.8 & 7.9 & 17.3 & 21.9 & 29.9 & 31.9 & 33.7 & 34.2 \\
$50 \%$ & 0.0 & 3.0 & 12.8 & 22.9 & 26.6 & 32.2 & 33.6 & 34.7 & 35.0 \\
$60 \%$ & 0.9 & 4.6 & 16.9 & 26.4 & 29.5 & 33.9 & 35.0 & 35.9 & 36.2 \\
$70 \%$ & 0.6 & 6.0 & 19.5 & 28.0 & 30.6 & 34.3 & 35.2 & 36.0 & 36.2 \\
$80 \%$ & 0.7 & 6.9 & 20.8 & 27.6 & 29.6 & 32.2 & 32.8 & 33.2 & 33.3 \\
$90 \%$ & 0.8 & 6.9 & 19.3 & 24.3 & 25.7 & 27.5 & 27.9 & 28.3 & 22.2
\end{tabular}

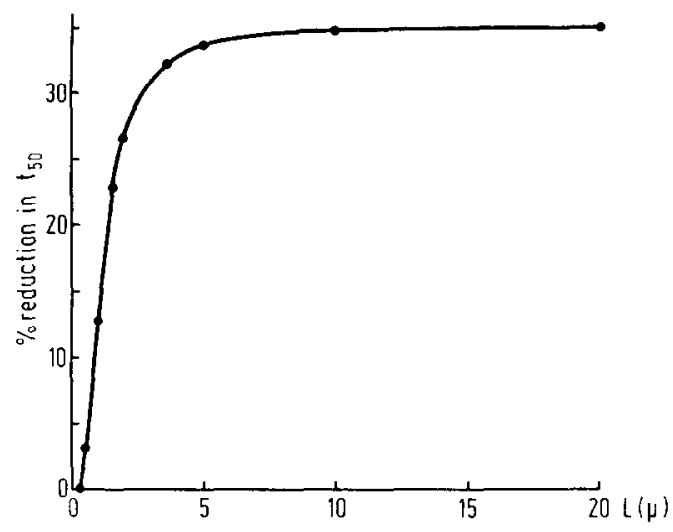

Fig. 3. The cffect of $\mathrm{HbO}_{z}$ diffusion on half-saturation time $\left(\mathrm{t}_{30}\right)$ as a function of layer thickness $(\mathrm{L})$.

I have investigated the role of $\mathrm{HbO}_{2}$ diffusion in $\mathrm{O}_{2}$ uptake by comparing solutions of the model for which $\mathrm{D}_{\mathrm{HbO}_{2}}=0$ to solutions for which $\mathrm{D}_{\mathrm{HbO}_{2}}=4.5 \times 10^{-8} \mathrm{~cm}^{2} / \mathrm{sec}$. The results are shown in table 4 and fig. 3 shows the percent reduction in $t_{50}$ attributable to $\mathrm{HbO}_{2}$ diffusion. For $\mathrm{L}=0.25 \mu$ the effect of $\mathrm{HbO}_{2}$ diffusion is small, the reduction in $t_{50}$ being 0 and the reduction in $t_{80}$ being $0.7 \%$. The influence of $\mathrm{HbO}_{2}$ diffusion rises with increasing $\mathrm{L}$ so that in the $5 \mu$ layer the reduction in $\mathrm{t}_{50}$ is about $35 \%$. I think this reflects the importance of reaction rates in the thinner layers and the primacy of diffusion processes in the thicker ones.

Similar computations were performed by MoLL (1968) for 1.6 and $3.6 \mu$ layers and my results agree well with his in spite of the facts that he used a different numerical method and recomputed $\mathrm{k}$ during the course of the calculations in order to match the $\mathrm{Hb}-\mathrm{O}_{2}$ equilibrium curve of human blood. I believe the close agreement is due to $\mathrm{k}$ being a relatively unimportant determinant of the rate of $\mathrm{O}_{2}$ uptake, an assertion supported in the next section. 
The thickness dependence of facilitation of $\mathrm{O}_{2}$ uptake may be compared to facilitation of steady-state $\mathrm{O}_{2}$ diffusion which, according to the calculations of KUTCHAI, JACQUEZ and MATHER (1970), also increases with layer thickness and asymptotically approaches a theoretical maximum. As layer thickness is increased, the facilitation of $\mathrm{O}_{2}$ uptake approaches its maximum value more quickly than does facilitation of steady-state $\mathrm{O}_{2}$ diffusion. For layers of the same thickness, however, the percent by which the $\mathrm{t}_{50}$ is decreased by $\mathrm{HbO}_{2}$ diffusion is less than the percent by which steady-state $\mathrm{O}_{2}$ flux is increased due to $\mathrm{HbO}_{2}$ diffusion.

THE RELATIVE IMPORTANCE OF $\mathrm{D}_{\mathrm{O}_{2}}, \mathrm{D}_{\mathrm{HbO}_{2}}, \mathrm{k}^{\prime}$, AND $\mathrm{k}$

Evidence has been presented that for thin layers the chemical reaction rates are the principal determinants of the $\mathrm{O}_{2}$ uptake rate and the influence of diffusion parameters increases with layer thickness. Because the effective thickness of the human $\mathrm{RBC}$ is probably close to $1.6 \mu$ I chose the $1.6 \mu$ model to make a more detailed study of the relative importance of diffusion and reaction parameters. For this purpose the model was solved for $20 \%$ increases in $\mathrm{D}_{\mathrm{O}_{2}}, \mathrm{D}_{\mathrm{HbO}_{2}}, \mathrm{k}^{\prime}$, and $\mathrm{k}$, one at a time and $\mathrm{k}^{\prime}$ and $\mathrm{k}$ together.

\section{TABLE 5}

The effects of diffusion and reaction parameters on oxygen uptake by $1.6 \mu$ layers of $32.25 \mathrm{~g} / \mathrm{ml}$ hemoglobin solution.

\begin{tabular}{|c|c|c|c|c|c|c|}
\hline \multirow[b]{2}{*}{$\begin{array}{l}\text { Avg. sat- } \\
\text { uration }\end{array}$} & \multicolumn{6}{|c|}{ time (msec) } \\
\hline & $\begin{array}{l}\text { Values of } \\
\text { table } 1\end{array}$ & $\begin{array}{l}20 \% \text { incr. } \\
\text { in } \mathrm{D}_{2}\end{array}$ & $\begin{array}{l}20 \% \text { incr. } \\
\text { in } \mathrm{D}_{\mathrm{HbO}_{2}}\end{array}$ & $\begin{array}{l}20 \% \text { incr. } \\
\text { in } k^{\prime}\end{array}$ & $\begin{array}{l}20 \% \text { incr. in } \\
\mathrm{k}^{\prime} \text { and } \mathrm{k}\end{array}$ & $\begin{array}{l}20 \% \text { incr. } \\
\text { in } \mathrm{k}\end{array}$ \\
\hline $10 \%$ & 1.38 & 1.27 & 1.39 & 1.25 & 1.25 & 1.39 \\
\hline $20 \%$ & 3.32 & 3.01 & 3.31 & 3.04 & 3.06 & 3.34 \\
\hline $30 \%$ & 5.86 & 5.26 & 5.79 & 5.44 & 5.51 & 5.93 \\
\hline $40 \%$ & 9.09 & 8.11 & 8.90 & 8.55 & 8.67 & 9.23 \\
\hline $50 \%$ & 13.04 & 11.60 & 12.66 & 12.38 & 12.59 & 13.29 \\
\hline $60 \%$ & 17.75 & 15.75 & 17.14 & 16.94 & 17.27 & 18.14 \\
\hline $70 \%$ & 23.37 & 20.70 & 22.49 & 22.35 & 22.84 & 23.98 \\
\hline $80 \%$ & 30.46 & 26.93 & 29.30 & 29.00 & 29.83 & 31.54 \\
\hline $90 \%$ & 43.03 & 38.02 & 41.58 & 39.31 & 42.03 & 48.88 \\
\hline
\end{tabular}

The results are given in table 5. For the initial rate of $\mathrm{O}_{2}$ uptake as indicated by $\mathrm{t}_{10}$ the parameters, listed in order of decreasing importance, are $\mathrm{k}^{\prime}, \mathrm{D}_{\mathrm{O}_{2}}, \mathrm{D}_{\mathrm{HbO}_{2}}$, and $\mathrm{k}$. As the oxygenation process proceeds $\mathrm{D}_{\mathrm{O}_{2}}$ becomes the most important parameter, $\mathrm{k}^{\prime}$ taking second place. This probably reflects the fact that in the early stages of $\mathrm{O}_{2}$ uptake the principal event is the reaction of $\mathrm{Hb}$ in the outer parts of the layer with $\mathrm{O}_{2}$, but that later the diffusion of $\mathrm{O}_{2}$ into the center of the layer is more important. In interpreting the effects of changing $\mathbf{k}^{\prime}$ or $\mathbf{k}$ alone it should be kept in mind that the affinity of $\mathrm{Hb}$ for $\mathrm{O}_{2}$ has been changed (this is important especially in the later stages of oxygenation when chemical equilibrium is approached). 
It should be noted that for $1.6 \mu$ layers of $\mathrm{Hb}$ solution none of the parameters is without significant influence on the rate of $\mathrm{O}_{2}$ uptake.

\section{COMPARISON OF $\mathrm{O}_{2}$ UPTAKE BY LAYERS OF Hb SOIUTION AND RBCS}

The uptake of $\mathrm{O}_{2}$ by the $\mathrm{RBC}$ is a relatively simple biological transport process, yet it is not completely understood. Some experiments suggest that the $\mathrm{O}_{2}$ diffusion resistance of the RBC membrane is insignificant and that the mobility of $\mathrm{O}_{2}$ and $\mathrm{Hb}$ is the same in RBCs as in concentrated $\mathrm{Hb}$ solutions. However, calculations which assume the RBCs to be a bag of concentrated $\mathrm{Hb}$ solution surrounded by a membrane of infinite $\mathrm{O}_{2}$ permeability jnvariably overestimate the rate of $\mathrm{O}_{2}$ uptake that is measured in a rapid reaction apparatus. I would now like to consider possible explanations of this discrepancy.

Theoretical calculation can be brought into agreement with experimental observations by assuming a sufficiently small $\mathrm{O}_{2}$ permeability for the $\mathrm{RBC}$ membrane (Roughton, 1959; Forster, 1964; Moll, 1968).

KREUZER and YAHR (1960) spectrophotometrically measured the rate of $\mathrm{O}_{2}$ uptake by 100-227 $\mu$ layers of packed RBCs and concentrated $\mathrm{Hb}$ solutions. They found no significant differences in $\mathrm{O}_{2}$ uptake rates between the cells and the solutions. Kutchai and Staub (1969) studied steady-state $\mathrm{O}_{2}$ diffusion through $165 \mu$ layers of packed RBCs and concentrated $\mathrm{Hb}$ solutions and found no difference in the $\mathrm{O}_{2}$ permeability or the extent of facilitated $\mathrm{O}_{2}$ transport in the two preparations. These experiments suggest that the resistance to $\mathrm{O}_{2}$ diffusion due to the $\mathrm{RBC}$ membrane is negligible in comparison to that of the cell interior.

Grote and THEws (1962) extimated $\mathrm{D}_{\mathrm{O}_{2}}$ in $\mathrm{RBCs}$ to be $0.8 \times 10^{-5} \mathrm{~cm}^{2} / \mathrm{sec}$, which is quite close to the values obtained in concentrated $\mathrm{Hb}$ solutions by KELLER and FriedLANDER (1966). The results of KutChaI and StaUb support the conclusion that $\mathrm{D}_{\mathrm{O}_{2}}$ in $\mathrm{RBCs}$ is similar to that in concentrated $\mathrm{Hb}$ solutions and also suggest that $\mathrm{D}_{\mathrm{HbO}_{2}}$ in RBC's is similar to that in concentrated $\mathrm{Hb}$ solutions. Thus differences in $\mathrm{D}_{\mathrm{O}_{2}}$ and $\mathrm{D}_{\mathrm{HbO}_{2}}$ probably cannot explain the discrepancy in $\mathrm{O}_{2}$ uptake rate between theory and experiment.

We must also consider the possibility that the rate of chemical reaction of $\mathrm{Hb}$ with $\mathrm{O}_{2}$ is different in $\mathrm{RBCs}$ than in dilute solutions of $\mathrm{Hb}$. (For technical reasons $\mathrm{k}^{\prime}$ and $\mathrm{k}$ have been determined only in dilute $\mathrm{Hb}$ solutions.) In order to fit my model to the experimentally observed initial rate of $\mathrm{O}_{2}$ uptake by deoxygenated $\mathrm{RBC}$ suspensions $\mathbf{k}^{\prime}$ must be lowered to about $2 \times 10^{8} \mathrm{ml} /(\mathrm{mole} . \mathrm{sec})$, which is 17 times smaller than the value in dilute $\mathrm{Hb}$ solutions.

It has been shown that organic phosphates present in the $\mathrm{RBC}$, especially 2,3diphosphoglycerate, have a dramatic effect on the $\mathrm{Hb}-\mathrm{O}_{2}$ equilibrium curve (see review by BENESCH and BENESCH, 1969) and hence must effect $k^{\prime}, k$, or both. Studies of the kinetic consequences of 2,3-disphosphoglycerate have not yet been reported. The discrepancy between observed and calculated rates of $\mathrm{O}_{2}$ uptake by RBCs may be due to the effects of intracellular organic phosphates on the rate constants. However, the rates of $\mathrm{CO}$ and NO uptake by RBCs are also considerably less than theoreti- 
cally predicted (see ForSTER, 1964) and it seems unlikely that the rates of reaction of $\mathrm{Hb}$ with $\mathrm{O}_{2}, \mathrm{CO}$, and $\mathrm{NO}$ should be affected to approximately the same extent by organic phosphates.

The possibility of an unstirred layer around the $\mathrm{RBC}$ in the rapid reaction apparatus has been considered by KoYAma and Mochizuki (1969). They studied the kinetics of $\mathrm{O}_{2}$ uptake by $\mathrm{RBCs}$ at three different flow velocities and found an increase in the rate of $\mathrm{O}_{2}$ uptake with increasing flow velocity.

Another possible explanation for the difference between theory and observation concerns the shape of the $\mathrm{RBC}$ in the rapid reaction apparatus. $\mathrm{RBCs}$ are known to be deformed in the flow in arterioles (BLOCH, 1962), thus they may be deformed in the rapid reaction apparatus.

CARLSEN and COMROE (1958) found the same rates of CO and NO uptake by human RBCs of normal discoidal shape and those made spherical by heating briefly to $49{ }^{\circ} \mathrm{C}$. Since the biconcave disc should theoretically take up gases by diffusion much faster than the sphere, it was concluded that intracellular diffusion is not important in determining the rate at which RBCs take up gases.

The results of CARLSEN and COMROE might be explained by shape changes of the RBCs in the rapid reaction apparatus. If both discoidal and spherical forms were continually being deformed in the turbulent stream, the 'average' shape might lie between the disc and the sphere. This might explain the results of CARLSEN and COMROE as well as the discrepancy between observed and predicted rates of $\mathrm{O}_{2}$ uptake by RBCs.

I conclude that we still cannot explain why RBCs take up gases considerably slower than theory predicts. An artefact of the rapid reaction apparatus may be involved or there may be some aspect of the gas uptake process that is poorly understood.

\section{Acknowledgements}

It is a pleasure to thank FranCES J. MATHER and OLA SVEEN for programming assistance and Drs. J. B. STEEN and W. MoLl for comments on the manuscript.

The project was supported by grants 5T1 GM 892-07 and 1 FO2 HE42933-01 from the National Institutes of Health.

\section{References}

BENESCH, R. and R. E. BENESCH, (1969). Intracellular organic phosphates as regulators of oxygen release by hemoglobin. Nature $221: 618-621$.

BLOCH, E. H. (1962). A quantitative study of the hemodynamics in the living microvascular system. Am. J. Anat. 110: 125-145.

CARLSEN, E. and J. H. ComRoe, JR. (1958). The rate of uptake of carbon monoxide and of nitric oxide by normal human erythrocytes and experimentally produced spherocytes. J. Gen. Physiol. 42: 83-107.

Carnahan, B., H. A. Luther and J. O. Wilkes (1969). Applied Numerical Methods. New York, John Wiley and Sons, p. 451.

Forster, R. E. (1964). Rate of gas uptake by red cells. In: Handbook of physiology. Section 3. Respiration. Vol. 1, edited by W. O. Fenn and H. Rahn. Washington, D. C., American Physiological Society, pp. 827-837. 
Gibson, Q. H., F. Kreuzer, E. Meda and F. J. W. Roughton (1955). The kinetics of human haemoglobin in solution and in the red cell at $37^{\circ} \mathrm{C}$. J. Physiol. (London) 129: 65-89.

Grote, J. and G. ThEws (1962). Die Bedingungen für die Sauerstoffversorgung des Herzmuskelgewebes. Pfügers Arch. ges. Physiol. 276: 142-165.

Hemmingsen, E. (1965). Accelerated transfer of oxygen through solutions of heme pigments. Acta Physiol. Scand. 64 (Suppl. 246): 1-53.

Holland, R. A. B. and R. E. Forster (1966). The effect of size of red cells on the kinetics of their oxygen uptake. J. Gen. Physiol. 49: 727-742.

Keller, K. H. and S. K. Friedlander (1966). The steady-state transport of oxygen through hemoglobin solutions. J. Gen. Physiol. 49: 663-679.

Klug, A., F. Kreuzer and F. J. W. Roughton (1956). Simultaneous diffusion and chemical reaction in thin layers of haemoglobin solutions. Proc. Roy. Soc. B 145: 452- 472.

Koyama, T. and M. MochIzUKI (1969). A study of the relationship between the oxygenation velocity of the red blood cell and the flow velocity in a rapid flow method. Jap. J. Physiol. 19: 534546.

KREUZER, F. and W. Z. YAHR (1960). Influence of the red cell membrane on diffusion of oxygen. J. Appl. Physiol. 15: 1117-1122.

Kutchal, H. and N. C. Stairs (1969). Steady-state, hemoglobin-facilitated $\mathrm{O}_{2}$ transport in human erythrocytes. J. Gen. Physiol. 53: 576-589.

KutchaI, H., J. A. JAQUeZ and F. J. MATHER (1970). Non-equilibrium facilitated oxygen transport in hemoglobin solution. Biophys. J. 10: 38-54.

Moll, W. (1966). Diffusion coefficient of hemoglobin. Respir. Physiol. 1 : 357-365.

MoLl, W. (1968). The influence of hemoglobin diffusion on oxygen uptake and release by red cells. Respir. Physiol. 6: 1-15.

Mols, W. (1969). Measurements of facilitated diffusion of oxygen in red blood cells at $37^{\circ} \mathrm{C}$. Pfügers Arch. ges. Physiol. 305: 269-278.

Nicolson, P. and F. J. W. Roughton (1951). A theoretical study of the influence of diffusion and chemical reaction velocity on the rate of exchange of $\mathrm{CO}$ and $\mathrm{O}_{2}$ between the red blood corpuscle and the surrounding fluid. Proc. Roy. Soc. B 138: 241-264.

Roughton, F. J. W. (1959). Diffusion and simultaneous reaction velocity in hemoglobin solutions and red cell suspensions. Progr. in Biophys. Biophys. Chem. 9: 55-104.

SAUL'Yev, V. K. (1964). Integration of Equation of Parabolic Type by the Method of Nets. New York, Macmillan.

Sendroy, J., JR., R. T. Dillon and D. D. van Slyke (1934). Studies of gas and electrolyte equilibria in blood. XIX. The solubility and physical state of uncombined oxygen in blood. J. Biol. Chem. 105: 597-632.

Wittenberg, J. B. (1966). Myoglobin-facilitated diffusion of oxygen. J. Gen. Physiol. 49: 57-74. 